\title{
Inventarisasi Kearifan Lokal Etnis Karo dalam Pemanfaatan Etnobotani di Kabupaten Karo
}

\author{
Sihar Pandapotan*, Khairat \& Syahril \\ Unit Program Belajar Jarak Jauh, Universitas Terbuka Medan, Indonesia
}

Diterima: Oktober 2018; Disetujui: Oktober 2018; Dipublish: Oktober 2018

*Email: pandapotansihar57@gmail.com

\begin{abstract}
Abstrak
Penelitian ini bertujuan untuk menginventarisasi berbagai bentuk kearifan lokal Etnis Karo dalam pemanfaatan berbagai jenis tumbuhan lokal, pengolahan secara medikal, pangan, kosmetika, ritual, dan papan. Tujuan lain adalah menganalisis potensi unsur mikro dan makro ekonomi pada pemasaran hasil olahan tumbuhan. Landasan berpikir dari penelitian ini ialah konsep etnobotani, etnoekologi, dan kearifan lokal. Penelitian ini menggunakan metode penelitian kualitatif dengan pendekatan deskriptif. Teknik pengumpulan data berupa observasi partisipasi, wawancara mendalam, studi dokumen, dan dokumentasi. Hasil penelitian mengungkapkan setidaknya terdapat 218 jenis tumbuhan lokal Etnis Karo yang tumbuh dan diketahui Etnis Karo khasiat dan kegunaannya. Tumbuhan lokal untuk medikal sejumlah 183 jenis, untuk bahan kuliner sejumlah 53 jenis, untuk kosmetika sejumlah 32 jenis, untuk magis sejumlah 27 jenis, dan untuk peratalan rumah tangga (papan) sejumlah 7 jenis. Tumbuhan/tanaman lokal yang berfungsi secara etnobotani ada yang memiliki fungsi ganda, sehingga total tumbuhannya bisa saja melebihi jumlah jenis tumbuhan/tanaman lokal yang dimanfaatkan warga. Adapun beberapa pengetahuan lokal Etnis Karo terkait pengolahannya diantaranya dihasilkan dalam bentuk pembuatan minyak karo, kuning/ param, menyuntil sirih, oukup, sembur beltek, ritual erpangir ku lau dan lain-lain.
\end{abstract}

Kata Kunci : Inventarisasi, Kearifan Lokal, Etnobotani, Etnis Karo

\begin{abstract}
This study aims to inventory various forms of Karo ethnic local wisdom in the use of various types of local plants, medical processing, food, cosmetics, rituals, and boards. Another goal is to analyze the potential of micro and macroeconomic elements in the marketing of processed plants. The cornerstone of thinking in this study is the concept of ethnobotany, ethnoecology, and local wisdom. This study uses qualitative research methods with a descriptive approach. Data collection techniques include participatory observation, in-depth interviews, document studies, and documentation. The results of the study revealed that there were at least 218 local Karo ethnic plants that grew and were known to be Karo ethnicity and their usefulness. Local plants for medical are 183 species, for culinary ingredients a total of 53 types, for cosmetics a total of 32 types, for magical number of 27 types, and for the cancellation of households (boards) of 7 types. Local plants / plants that function ethnobotany are those that have multiple functions, so that the total number of plants can exceed the number of local plants / plants used by the people. As for some of the Karo Ethnic local knowledge related to its processing, it was produced in the form of making karo oil, yellow/param, injecting betel nut, enough, spraying beltek, my erpangir rituals and others.
\end{abstract}

Keywords: Inventory, Local Wisdom, Ethnobotany, Ethnic Karo

How to Cite: Pandapotan, S. Khairat \& Syahril. (2018) Inventarisasi Kearifan Lokal Etnis Karo dalam Pemanfaatan Etnobotani di Kabupaten Karo. Journal of Education, Humaniora and Social Sciences (JEHSS). 1 (1): 43-50.

\section{PENDAHULUAN}

Berbicara tentang pemanfaatan tumbuhan herba pada umumnya sebenarnya bukanlah hal yang baru. Sejak kemunculan manusia di muka bumi, alam telah ada. Dari alamlah manusia berupaya memenuhi kebutuhan hidupnya termasuk keperluan pangan, obat-obatan, kosmetika, ritual, dan sebagainya dalam rangka mengatasi berbagai persoalan hidup yang dihadapinya.

Berdasarkan aspek sejarah, sejak manusia memenuhi kebutuhan hidupnya dengan mata pencaharian hidup berburu dan meramu tersebut, manusia telah mengenal dan memanfaatkan berbagai tumbuhan baik sebagai bahan makanan, medikal, kosmetika, maupun ritual. Pengetahuan tentang pemanfaatan tumbuhan lokal tersebut merupakan warisan budaya bangsa berdasarkan pengetahuan dan pengalaman yang diwariskan secara turun-temurun hingga ke generasi sekarang. Oleh karena itu, diperlukan pemahaman terhadap budaya lokal (dalam hal ini terkait tumbuhan dan tanaman lokal) yang bermanfaat pada berbagai ranah kehidupan masyarakat Indonesia, agar pengetahuan lokal ini tidak 
menghilang begitu saja, seperti halnya saat ini generasi muda bangsa yang seakan kehilangan mutu budi pekerti dalam membangun integritas dirinya.

Namun pengetahuan masyarakat sepertinya tidak seimbang dengan keberagaman jenis tanaman/ tumbuhan yang hidup di tanah air ini. Secara umum masih ada masyarakat yang tidak mengetahui secara jelas fungsi/ manfaat/ khasiat tumbuhan - tumbuhan lokal. Pengetahuan yang dimiliki hanya sebatas pemahaman yang diturunkan oleh para nenek moyang yang disampaikan secara lisan. Kelemahan dalam penulisan atau pendokumentasian tersebut membuat pengetahuan tentang tumbuhan lokal tidak terdata secara holistik bahkan berhenti pada satu generasi tertentu. Sehingga negara kehilangan karakteristik/ ciri khas kearifan lokal bangsanya. Akan tetapi sebaliknya, seiring dengan berjalannya waktu dan perkembangan riset teknologi, ada beberapa tumbuhan berkhasiat yang tidak diketahui para nenek moyang atau generasi sebelumnya yang saat ini tengah terlestari, semisal kulit buah manggis. Atau sebaliknya, para generasi muda menganggap beberapa tumbuhan sebagai benalu seperti halnya patikan Cina. Masyarakat menganggap tumbuhan tersebut hanya akar - akaran yang menimbulkan kesemakan di pekarangan rumah. Padahal patikan cina dapat berkhasiat sebagai tumbuhan herba, salah satunya dapat mengobati gatal - gatal pada kulit.

Masyarakat Indonesia sebagai pelestari tumbuhan/tanaman berkhasiat memiliki peran penting dalam pembudidayaannya. Inventarisasi tumbuhan lokal menjadi penting untuk dilakukan sebagai kekuatan bangsa dalam ranah revitalisasi budaya lokal. Dunia medis akhir-akhir malah malah mempublikasikan berbagai tumbuhan lokal yang berkhasiat dalam bidang pengobatan. Selain itu, sosialisasi kepada warga masyarakat juga diperlukan agar apa yang dimiliki negara ini dapat tumbuh subur dan dimanfaatkan oleh warga sendiri, baik sebagai ilmu pengetahuan maupun sebagai obat herbal yang bermanfaaat.

Hingga saat ini, berbagai tumbuhan lokal tetap hidup di wilayah Indonesia, khususnya pada wilayah Sumatera Utara. Warga Sumatera Utara kerap memanfaatkan olahan tumbuhan herba pada salah satu etnis yang terdapat di wilayah ini. Ialah minyak karo sebagai salah satu olahan tumbuhan herba yang telah sangat dikenal manfaatnya bagi khalayak ramai. Minyak karo pada Etnis Karo menjadi contoh betapa pentingnya penanaman tumbuhan/ tanaman lokal sebab berbagai kandungan tumbuhan di dalamnya yang sangat berkhasiat. Adapun tumbuhan lokal yang digunakan dalam pembuatan minyak karo ialah daun sirih, buayah mayang, rempah ratus, akar mayang, pala, bahing, bawang putih, bawang merah, pinang, lada, jahe, akar-akar rumput, binara, serai, binahok, rempah ratus, dan puluhan tumbuhan herba khas tanah karo. Pembuatan minyak karo yang berkualitas juga tidak dapat dilakukan secara sembarangan. Mungkin dapat dibayangkan bila tidak ada inventarisasi dan dokumentasi yang jelas terkait hal tersebut, menjadi kerugian yang besar bagi negara karena kehilangan pengetahuan lokal yang luar biasa ini.

Pada satu contoh olahan tumbuhan lokal (minyak karo) Etnis Karo tersebut, telah menjadi alasan mendasar betapa pentingnya penelitian ini untuk mengumpulkan, menginventarisasi, mengidentifikasi, mengklasifikasi, dan menganalisis berbagai tanaman dan tumbuhan lokal pada masing-masing wilayah penananamannya. Tanaman dan tumbuhan lokal yang terinventarisasi kemudian ditelaah lebih mendalam manfaat dan fungsinya sesuai dengan kajian etnobotani, menemukan pengolahan dan potensi peningkatan ekonominya. Hal tersebut sebagaimana diutarakan Suryadarma (2008) bahwa etnobotani menekankan bagaimana mengungkap keterkaitan budaya masyarakat dengan sumberdaya tumbuhan di lingkungannya secara langsung ataupun tidak langsung. Penekanannya pada hubungan mendalam budaya manusia dengan alam nabati sekitarnya. Mengutamakan persepsi dan konsepsi budaya kelompok masyarakat dalam mengatur sistem pengetahuan anggotanya menghadapi tetumbuhan dalam lingkup hidupnya.

Etnobotani yaitu bidang ilmu yang mempelajari hubungan timbal balik antara manusia dengan sumberdaya alam tumbuhan dan lingkungannya. Etnobotani merupakan perpaduan antara ilmu pengetahuan alam dan ilmu sosial, salah satunya adalah pengetahuan sosial budaya. Etnobotani mengikuti perkembangan yang berlangsung antara kehidupan suatu etnik dalam bidang botani, yang dipengaruhi oleh perkembangan yang sifatnya global. (Munawaroh \& Inggit 2000).

Sedangkan menurut Dharmono (2007) menekankan bahwa etnobotani merupakan ilmu botani mengenai pemanfaatan tumbuhan dalam keperluan sehari-hari dan adat suku bangsa. Studi etnobotani tidak hanya mengenai data botani taksonomis saja, tetapi juga menyangkut pengetahuan botani yang bersifat kedaerahan, berupa tinjauan interpretasi dan asosiasi yang mempelajari hubungan timbal balik antara manusia dengan tanaman, serta menyangkut pemanfaatan tanaman tersebut lebih diutamakan untuk kepentingan budaya dan kelestarian sumber daya alam.

Etnobotani dapat terdiri atas berbagai fungsi, diantaranya fungsi pangan, fungsi medikal (pengobatan), fungsi kosmetika, dan fungsi ritual. Menurut Bangun (2009: 12-16), tanaman obat telah lama digunakan oleh nenek moyang dan memberi hasil yang baik dalam pengobatan penyakit dan 
pemeliharaan kesehatan. Selama berabad-abad banyak tanaman yang berkhasiat sebagai obat berbagai jenis penyakit. Sedangkan pada ranah pangan, telah ditelusuri melalui sistem mata pencaharian yang paling tua yakni meramu, yang mana manusia beradaptasi dengan lingkungan setempat untuk dapat memilah berbagai tanaman yang dapat dikonsumsi, menjadi obat, menghias wajah, bahkan setiasa digunakan sebagai ritual dalam perjalanan manusia menemukan religinya.

Salah satu kajian keilmuan/ sains dalam hal etnobotani yakni ethnoecologyyangmerupakan sains yang bertumpu pada kebutuhan praktis dan pengetahuan tersebut bersumber dari ilmu pengetahuan; anthrophology, ethnobiology, agronomy, environmental geography sebagai dasar pendekatannya (Toledo, 1992). Kajiannya bertumpu pada bagaimana pemanfaatan alam oleh kelompok masyarakat (ethnic) sesuai ragam kepercayaan, pengetahuan, tujuannya dan bagaimana pandangan kelompok etnis bersangkuatan dalam pemanfaatannya (Toledo 1992). Oleh karena itu penelitian ini diperlukan karena meskipun pada satu tanaman atau tumbuhan yang sama, akan terjadi perbedaan makna dalam penggunaan tanaman atau tumbuhan tersebut berdasarkan pengetahuan lokal masyarakat yang berbeda.

Indigenous knowledge dapat dikatakan suatu keunikan dalam satu kultur masyarakat, pengetahuan asli, pengetahuan lokal dan nilai-nilai tradisional. Pengetahuan bidang pertanian, penyediaan bahan pangan, perlindungan alam, menjaga kesehatan. Sistem pewarisannya dilakukan secara lisan, menggunakan ungkapan kata-kata dalam upacara, ritual, adat istiadat yang bertumpu pada bidang kehidupan praktis (Gough, 1977).

Masyarakat lokal mengembangkan pengetahuan tradisionalnya secara praktis dimana mereka melangsungkan kehidupannya (Fien, 1977). Oleh karenanya, segala tanaman alam yang tumbuh di lingkungan sekitar dipelajari secara turun temurun oleh satu generasi ke generasi lainnya.

Narrol (1996) dalam Kumbara (2004), kelompok etnis dipahami sebagai populasi orang atau penduduk yang memiliki ciri ciri yang unik, yang diakui oleh etnik lainnya. Keunikannya antara lain tercermin pada ciri-ciri berikut; (1) mampu berkembanbiak dan bertahan secara biologis, (2) mempunyai nilai -nilai budaya yang sama, dan sadar akan rasa kebersamaan, (3) membentuk jaringan komunikasi dan interaksi, (4) memiliki ciri kelompok tersendiri yang diterima oleh kelompok lain, sehingga dapat dibedakan dengan kelompok lainnya. Keseluruhan masalah etnis mengacu aspek biologis, kepercayaa, pengetahuan budaya, bahasa, adat istiadat yang diwarisi dan keagamaan.

Local genius merupakansecara keseluruhan setara dengan cultural identity, yaitu kepribadian budaya satu bangsa. Terdapat berbagai pandangan tentang local genius, tetapi semua merujuk pada kolektivitas kelompok tertentu. Kepribadian kebudayaan lokal (Mundardjito), dan Soeodiman mengemukakan lima alternatif, yaitu (1) identitas kebudayaan, (2) identitas bangsa, (3) kebudayaan asli, (4) kebudayaan tradisional dan (5) kepribadian (dalam Ardhana, 2004).

Kearifan lokal merupakan salah satu hal yang menarik untuk dibicarakan di zaman modern yang serba canggih seperti sekarang ini. Menurut Gobyah (2003), kearifan lokal (local genius) adalah kebenaran yang telah mentradisi atau ajeg dalam suatu daerah. Kearifan lokal merupakan bentuk pengetahuan, keyakinan, pemahaman, dan kebiasaan sebagai produk budaya masa lalu yang memiliki keunggulan setempat sehingga melembaga secara tradisional dan menjadi pedoman hidup masyarakat. Nilai-nilai kearifan lokal diwariskan dari generasi ke generasi melalui sosialisasi dan enkulturasi yang terinternalisasi pada setiap individu dalam masyarakat sehingga memiliki kepribadian yang sesuai dengan norma.

Kearifan lokal merupakan salah satu menifestasi kebudayaan karena muatan kearifan tradisional suatu masyarakat adalah konsepsi dari nilai, ide dan pola tindakan yang dimiliki bersama sebagai sebuah sistem yang cenderung memegang erat tradisi, sebagai sarana untuk memecahkan persoalan yang sering dihadapi oleh masyarakat lokal. Kearifan lokal didefinisikan sebagai kebenaran yang telah mentradisi atau ajeg dalam suatu daerah (Gobyah, 2003).

Kearifan (wisdom) secara etimologi berarti kemampuan seseorang dalam menggunakan akal pikirannya untuk menyikapi sesuatu kejadian, obyek atau situasi. Sedangkan lokal, menunjukkan ruang interaksi dimana peristiwa atau situasi tersebut terjadi. Dengan demikian, kearifan lokal secara substansial merupakan norma yang berlaku dalam suatu masyarakat yang diyakini kebenarannya dan menjadi acuan dalam bertindak dan berperilaku sehari-hari. Oleh karena itu, kearifan lokal merupakan entitas yang sangat menentukan harkat dan martabat manusia dalam komunitasnya (Geertz, 1999).

Selama ini kearifan lokal sering diartikan sebagai kebijakan setempat (local wisdom), pengetahuan setempat (local knowledge) atau kecerdasan setempat (local genius) Purba (dalam Siswadi, 2010). Konsep kearifan lokal dimaknai sebagai pengetahuan yang khas milik suatu masyarakat atau budaya tertentu (indigenous pshycology), telah berkembang sekian lama, sebagai hasil dari proses hubungan timbal-balik antara manusia dengan lingkungannya.

Kearifan lokal berkembang dengan cara-cara dan praktek-praktek yang di kembangkan manusia, dari pemahaman mendalam mereka akan lingkungan setempat/lokal. Diwariskan secara turun-temurun 
secara lisan atau melalui pengetahuan dan tindakan. Kearifan lokal berasal dari dalam masyarakat itu sendiri, disebarluaskan secara non-formal dan milik kolektif anggota masyarakat yang bersangkutan dalam sebuah kesatuan. Nilai-nilai dan pengetahuan lokal tertanam di dalam cara hidup masyarakat sebagai sarana untuk bertahan hidup survival (Arkanuddin, 2007).

Menurut (Ridwan, 2007) kearifan lokal secara esensial berisikan gambaran dan pengetahuan (kognitif) masyarakat tentang hal-hal yang berkaitan dengan struktur lingkungan, bagaimana lingkungan berfungsi, bagaimana reaksi alam atas tindakan manusia, serta hubungan-hubungan yang sebaiknya tercipta antara manusia dan lingkungan alamnya. Salah satu wujud dari pengetahuan mereka adalah terciptanya suatu sistem pengelolaan sumber daya alam. Berbagai tradisi, upacara adat, dan tindakan sehari-hari manusia mengandung makna yang dalam atas hubungan mereka dengan lingkungannya.

Syafaat (dalam Bathlimus, dkk. 2007) menggambarkan kearifan lokal secara defenitif, yang merupakan pandangan hidup yang sudah mentradisi mengenai hubungan antar komunitas atau antara warga masyarakat dengan lingkungan hidup mereka.

\section{METODE PENELITIAN}

Metode penelitian yang digunakan ialah kualitatif deskriptif. Metode kualitatif deskriptif adalah upaya yang dapat menjabarkan secara jelas terkait data-data yang dibutuhkan dalam penelitian secara desktiptif. Penelitian kualitatif dengan pendekatan deskriptif diperlukan karena peneliti ingin mendeskripsikan secara jelas dan terperinci untuk memeroleh data yang mendalam tentang kearifan lokal Etnis Karo terkait pemanfaatan tumbuhan lokal Karo. Pendeskripsian ini penting untuk mampu menguraikan dengan jelas khasiat berbagai tumbuhan lokal Karo dalam bidang medikal, kuliner/pangan, kosmetika, ritual, dan papan. Lokasi penelitian berada di Kabupaten Karo. Informan utama adalah etnik Karo yang menanam, memiliki hutan, mengumpulkan tumbuhan/tanaman lokal Etnik Karo, memahami penggunaan tanaman/tumbuhan lokal, dan mengolah tanaman/tumbuhan lokal. Sedangkan informan pendukung dalam penelitian ini ialah kepala desa, perangkat desa, dan masyakarat pengguna tanaman lokal Karo. Pengumpulan data dalam penelitian kualitatif ini menggunakan beberapa teknik pengumpulan data. Pada penelitian ini digunakan teknik pengumpulan data dengan (a) observasi (b) wawancara mendalam (in depth interview) dan (c) dokumentasi. Teknik analisis data yang dilakukan dalam penelitian ini adalah analisis data model kualitatif seperti yang pernah dilakukan oleh Miles dan Huberman (dalam Iskandar, 2009) yang terdiri dari tiga kegiatan yaitu reduksi data, penyajian data, dan penarikan kesimpulan.

\section{HASIL DAN PEMBAHASAN}

\section{Inventarisasi dan Identifikasi Jenis-Jenis Tumbuhan Lokal Etnis Karo}

Pada penelitian ini, jenis-jenis tumbuhan dan tanaman lokal diinventarisasi melalui berbagai desa di Kabupaten Karo. Masing-masing desa di wilayah Karo ternyata memiliki pengetahuan lokal yang berbeda terkait pemanfaatan tumbuhan lokal yang tumbuh di wilayah ini. Secara umum, jenis tumbuhan/ tanaman lokal diklasifikasikan ke dalam tiga jenis yaitu tumbuhan lokal liar yang tumbuh baik di sekitar pekarangan rumah warga maupun yang tumbuh di hutan rakyat, tanaman lokal yang dibudidayakan oleh masyarakat setempat, dan tanaman/tumbuhan lokal yang diperoleh melalui kem-kem (toko herba Karo). Selanjutnya, jenis tumbuhan tersebut diklasifikasikan ke dalam beberapa fungsi etnobotani yakni sebagai medikal, kuliner/pangan, kosmetika, ritual, dan papan.

Adapun jumlah tumbuhan lokal yang ditemukan sebanyak 218 jenis tumbuhan. Sedangkan untuk fungsi etnobotani sebagai medikal (pengobatan) terdapat sejumlah 183 jenis tumbuhan. Sebagai bahan masakan (kuliner) terdapat sejumlah 53 jenis tumbuhan. Sedangkan sebagai bahan kosmetika terdapat sejumlah 31 jenis tumbuhan. Sebagai bahan praktek magis atau ritual, digunakan sejumlah 27 jenis tumbuhan. Terakhir, sebagai bahan peralatan rumah tangga (papan) ditemukan sejumlah 7 jenis tumbuhan. Namun demikian, terdapat beberapa jenis tumbuhan yang juga memiliki fungsi ganda, seperti halnya jeruk purut yang digunakan sebagai ramuan obat pada minyak karo dan digunakan sebagai bahan untuk kegiatan erpangir kulau, kencur (kacihur) digunakan sebagai param untuk kecantikan, tetapi juga digunakan sebagai bahan rempah untuk memasak. Oleh karena itu, tabulasi data di bawah ini akan menampilkan jumlah tumbuhan yang melebihi total jenis tumbuhan yang diperoleh karena beberapa fungsinya yang ganda.

Selanjutnya, berikut ini dipaparkan beberapa nama-nama jenis tumbuhan dan tanaman lokal yang ditemukan di wilayah Kabupaten Karo berdasarkan nama lokal, nama latin, dan pembagian tersendiri fungsi etnobotaninya. Nama-nama tumbuhan dan tanaman tersebut bisa jadi memiliki perbedaan nama 
tumbuhan pada wilayah di tempat lain. Hal ini disesuaikan dengan pengetahuan lokal masyarakat di lokasi penelitian.

Tabel 1.

20 Nama-Nama Tumbuhan dan Tanaman Lokal di Wilayah Kabupaten Karo

\begin{tabular}{|c|c|c|c|c|c|c|c|c|}
\hline No & Nama Tumbuhan & Nama local & Nama Latin & $\begin{array}{l}\text { Medi- } \\
\text { kal }\end{array}$ & $\begin{array}{l}\text { Kuli- } \\
\text { ner }\end{array}$ & $\begin{array}{l}\text { Kosme- } \\
\text { tika }\end{array}$ & $\begin{array}{l}\text { Ri- } \\
\text { tual }\end{array}$ & $\begin{array}{l}\text { Pa- } \\
\text { pan }\end{array}$ \\
\hline 1 & Jahe Merah & Bahing & $\begin{array}{l}\text { Zingiber officinale } \\
\text { Rosc. }\end{array}$ & $\sqrt{ }$ & $\sqrt{ }$ & $\sqrt{ }$ & - & - \\
\hline 2 & Lada Hitam & Lada Mbiring & Piper Nigrum L. & $\sqrt{ }$ & $\sqrt{ }$ & $\sqrt{ }$ & - & - \\
\hline 3 & Daun Kapulaga & Bulung Kapulaga & $\begin{array}{l}\text { Amomum } \\
\text { compactum Sol. Ex } \\
\text { Maton }\end{array}$ & $\sqrt{ }$ & - & - & - & - \\
\hline 4 & Temu Gajah & Lempuyang Gajah & $\begin{array}{l}\text { Zingiber Zerumbet } \\
\text { Linn }\end{array}$ & $\sqrt{ }$ & - & - & - & - \\
\hline 5 & Temu Kunci & Lempuyang & $\begin{array}{l}\text { Curcuma } \\
\text { xanathrriza Roxb }\end{array}$ & $\sqrt{ }$ & $\sqrt{ }$ & - & - & - \\
\hline 6 & Temu Hitam & Temu Hitam & $\begin{array}{l}\text { Curcuma } \\
\text { aeruginosa Roxb. }\end{array}$ & $\sqrt{ }$ & - & - & - & - \\
\hline 7 & Lazza (Temu Giring) & Kuning Gajah & $\begin{array}{l}\text { Curcuma } \\
\text { Heyneana }\end{array}$ & $\sqrt{ }$ & - & $\sqrt{ }$ & - & - \\
\hline 8 & Bawang Merah & Pia & $\begin{array}{lr}\text { Alliu cepa } & \text { var } \\
\text { ascalonicum } & \text { (L) } \\
\text { Back } & \end{array}$ & $\sqrt{ }$ & $\sqrt{ }$ & - & - & - \\
\hline 9 & Jahe Putih & Bahing Mbentar & Zingiber officinale & $\sqrt{ }$ & $\sqrt{ }$ & $\sqrt{ }$ & - & - \\
\hline 10 & Jeruk Pagar & Rimo Pagar & Jatropha curcas & $\sqrt{ }$ & & - & $\sqrt{ }$ & - \\
\hline 11 & Rimo Puraga & Jeruk Puraga & Rutaceae & - & - & - & $\sqrt{ }$ & - \\
\hline 12 & Serai Wangi & Serai Wangi & $\begin{array}{l}\text { Cymbopogon } \\
\text { nardus (L.) Rendle }\end{array}$ & $\sqrt{ }$ & - & $\sqrt{ }$ & - & - \\
\hline 13 & Cengkih & Cengkeh & $\begin{array}{l}\text { Syzygium } \\
\text { aromaticum }\end{array}$ & $\sqrt{ }$ & $\sqrt{ }$ & - & - & - \\
\hline 14 & Kencur & Kacihur & $\begin{array}{l}\text { Kaempferia } \\
\text { galanga } \mathrm{L}\end{array}$ & $\sqrt{ }$ & $\sqrt{ }$ & $\sqrt{ }$ & - & - \\
\hline 15 & Bawang Putih & Lasuna & Allium sativum & $\sqrt{ }$ & $\sqrt{ }$ & - & $\sqrt{ }$ & - \\
\hline 16 & $\begin{array}{l}\text { Jintan Hitam/ Daun } \\
\text { Bangun-bangun }\end{array}$ & Daun Terbangun & $\begin{array}{l}\text { Plectranthus } \\
\text { amboinicus L. }\end{array}$ & $\sqrt{ }$ & $\sqrt{ }$ & - & - & - \\
\hline 17 & Kecombrang & $\begin{array}{l}\text { Cekala/ Cinur } \\
\text { Patikala }\end{array}$ & Etlingera elatior & $\sqrt{ }$ & $\sqrt{ }$ & - & - & - \\
\hline 18 & Jeruk Purut & Rimo Mungkur & Citrus hystrix & $\sqrt{ }$ & - & - & $\sqrt{ }$ & - \\
\hline 19 & Andong/ Hanjuang & Daun Kalinjuhang & Cordyline Fruticosa & $\sqrt{ }$ & - & - & $\sqrt{ }$ & . \\
\hline 20 & Batang Nangka & Batang Nangka & $\begin{array}{l}\text { Artocarpus } \\
\text { heterophyllus }\end{array}$ & - & - & - & - & $\sqrt{ }$ \\
\hline
\end{tabular}

Analisis Bentuk Kearifan Lokal Etnis Karo dalam Pemanfaatan Tumbuhan Lokal d Kabupaten Karo

Etnis Karo sebagai mayoritas masyarakat yang menghuni wilayah Kabupaten Karo, telah memiliki hubungan yang erat dengan alam. Kebudayaan sebagai sistem pengetahuan, digunakan etnis ini untuk memahami dan menginterpretasikan lingkungan dan pengalamannya. Melalui pengetahuan kebudayaan inilah, Etnis Karo menciptakan berbagai kearifan lokalnya dalam pemanfaatan tumbuhan. Apalagi wilayah Karo sangat didukung dengan tekstur wilayah yang terkenal dengan kesuburannya. Sehingga beragam jenis tumbuhan dapat tumbuh subur di wilayah ini.

Dominasi lingkungan nyatanya berperan penting dalam memainkan peran dominan Etnis Karo sebagai pengguna tumbuhan lokal. Etnis ini menghasilkan berbagai sistem pengetahuan lokal dalam hal mengolah berbagai tumbuhan yang ada. Bahkan sangking kuatnya dominasi lingkungan, mendorong etnis ini untuk mengembangkan berbagai ritus-ritus yang berhubungan antara alam dan kekuatan gaib (supranatural) dengan memanfaatkan berbagai tumbuhan lokal yang dianggap memiliki makna magis pula. Berikut ini berbagai bentuk kearifan lokal yang dimiliki Etnis Karo dalam memanfaatkan tumbuhan di wilayahnya.

\section{Pembuatan Minyak Karo}

Pembuatan minyak karo merupakan salah satu bentuk kearifan lokal yang sangat terkenal pada kebudayaan Karo. Minyak karo terdiri dari olahan rempah dalam bentuk minyak yang berguna untuk menyembuhkan berbagai penyakit, seperti pegal linu, terkilir, salah urat, masuk angin, pergeseran pada 
sendi, asam lambung, sakit kepala, alergi dan sebagainya. Pada beberapa wilayah, komposisi yang terkandung pada minyak karo berbeda-beda. Seperti contoh, Di Desa Lingga, salah satu warga menambahnya dengan kandungan minyak monyet dan minyak ular untuk kegiatan ndikar (bergulat). Adapun rempahnya terdiri atas minyak kelapa, minyak monyet, minyak ular piton, minyak harimau/kucing, minyak wijen, minyak kelapa hijau, akar rotan (ketang), akar aren (enau), akar pinang, akar pohon besi-besi, akar bambu kuning (hurgen) akar tuba, akar kelapa, parem nek miting-miting. Apabila membeli di kem-kem (toko herba Karo) untuk membuat olahan minyak karo diperlukan bahan antara lain minyak, lada, bawang putih, pala, serai wangi, cengkeh, bawang merah, jeruk kuku harimau, daun paris dan rempah ratus yang terdiri atas ratusan rempah-rempah. di Desa Sukarame menggunakan 35 jenis tumbuhan, beberapa diantaranya seperti minyak bimoli, bulung lancing, gambir, buah pala, sere belanda, bulung rimo mukur, bulung rimo malam, buah cengkeh, akar-akaran, dan lain sebagainya. Semua rempah direbus selama beberapa jam (durasi waktu antara 1 hingga 4 jam).

Di Desa Sukarame, para lansia sejumlah 22 orang diberdayakan oleh pemerintah desa untuk mengolah minyak urut karo. Adapun besaran modal awal yang diberikan sebesar Rp.5.000.000,- sekali pemasakan. Bahan-bahan yang diolah selain dibeli di Pasar Kabanjahe, juga ada yang berasal dari ladang dan hutan para lansia. Sekali pemasakan membutuhkan waktu 1-2 hari hingga pengemasan. Minyak karo yang telah diolah dan dikemas, kemudian dipasarkan oleh para lansia. Pemasarannya beragam. Ada yang berada di Desa Sukarame, adapula yang berada di luar Sumatera Utara. Minyak urut per botolnya dijual dengan harga yang beragam, mulai Rp.25.000 hingga Rp. 100.000. Adapun keuntungan bersih rata-rata sekali pemasaran adalah sekitar Rp.100.000- Rp.200.000 per lansia per 80 liter. Setiap lansia menyisihkan keuntungan kotor sebagai modal kembali untuk pembuatan minyak karo berikutnya.

\section{Kuning/Param}

Kuning adalah sejenis olahan rempah yang dimanfaatkan untuk menghilangkan nyeri pada otot/ sendi dengan cara dibalur pada tubuh. Selain itu, kuning juga dapat digunakan di wajah untuk menghangatkan tubuh saat cuaca dingin. Kuning juga berkhasiat untuk memproteksi diri agar terhindar dari gigitan nyamuk. Salah satu bentuk kuning ialah kuning melas yang dibalurkan pada seluruh tubuh setelah dilakukan pemijatan oleh pemijat sebelum melaksanakan oukup, terdiri dari 20 jenis rempah yang dihaluskan. Adapun rempah-rempah yang ialah bawang merah (pia), temu kunci, merica (lada),bawang putih (lasuna), ketumbar (jaira), kencur (kacihur), rumput angin (sirang-sirang gumis), temulawak (kuning terbabana), temu putih (mburlai), sepenggel kuda, lempuyang gajah (lempuyang mbiring), temu hitam, jerangau (jeringo), kunyit putih (kuning mbentar), cinggrong (bulung kancing), serai, rumput paitan, jejarongan (paha bengkil), jahe putih (bahing), dan temu giring.

Akan tetapi, pada umumnya tanaman herba yang digunakan ialah temulawak, bangle, lempuyang, jerango, kencur, kuning gajah, merica, bawang putih, bawang merah, dan lada hitam. Bahan yang ada kemudian dibersihkan, diparut atau digiling hingga halus. Kemudian semua bahan disaring untuk memisahkan air dengan rempahnya. Bahan yang telah disaring selanjutnya dicampur tepung pulut dan dibentuk bulat-bulat untuk kemudian dikeringkan melalui proses penjemuran. Penggunaan kuning yang telah kering bisa dilakukan dengan menambah air untuk dibalurkan. Harga kuning berkisar dari Rp. 5000 hingga Rp. 35.000 tergantung dari banyaknya butir kuning. Beberapa pembuat kuning biasanya terdiri dari para perempuan Karo baik muda maupun tua, para pengobat patah tulang, maupun pedagang biasa di Pasar Kabanjahe.

\section{Menyuntil Sirih}

Di Desa Jaranguda dan beberapa desa lainnya, tradisi menyirih sudah menjadi kebudayaan turun temurun. Mulai dari remaja hingga orang tua (khususnya para perempuan sudah mentradisikan kegiatan menyuntil sirih sebagai bagian dari kehidupannya. Kegiatan man belo ras nyuntil merupakan pengetahuan lokal Etnis Karo yang berkhasiat untuk menguatkan gigi. Selain itu juga berfungsi untuk meredakan luka berdarah pada bagian tubuh yang tergores. Kegiatan menyuntil dimulai dengan meletakkan kapur sirih, beberapa potong buah pinang, gambir, bahkan tembakau di atas lembaran daun sirih. Kemudian daun sirih dilipat dan dimasukkan ke dalam mulut yang letaknya diantara gigi dan putih, selanjutnya dikunyah. Daun sirih sebagaimana diketahui secara umum mengandung zat antiseptik untuk mengobati berbagai penyakit seperti mimisan, keputihan, mengatasi mata yang memerah dan hal lainnya. Disamping itu tradisi menyuntil/menyirih pada Etnis Karo merupakan suatu adat istiadat yang sudah berlangsung lama yang pada mulanya dimaknai sebagai bentuk penghormatan, berbagai upacara dan ritual, dan kegiatan merdang. 


\section{Oukup}

Oukup berarti uap panas rempah-rempah. Kegiatan beroukup dapat berupa menghirup uap dari rempah-rempah yang telah direbus. Selain itu dapat dilakukan dengan pemijatan dengan menggunakan kuning selama beberapa menit. Pada masa dulu, kegiatan beroukup hanya dilakukan ibu-ibu yang telah melahirkan dengan tujuan untuk meningkatkan kembali stamina tubuhnya. Akan tetapi, saat ini, oukup tidak hanya dilakukan untuk para ibu, tetapi juga bagi khalayak dengan segala usia. Secara umum, oukup berkhasiat sebagai pengobatan tradisional Etnis Karo untuk menyembuhkan penyakit dengan cara mandi pada uap panas yang telah diramu dengan berbagai rempah. Adapun khasiat lainnya untuk meredakan saraf urat yang terjepit, meningkatkan daya tahan tubuh, menyegarkan badan, menghaluskan kulit, dan melancarkan peredaran darah. Beberapa rempah diantaranya, cekala, serai wangi, bawang merah, jahe putih, lada hitam, daun sembung, temu giring, temu kunci, daun sirih, cengkeh, lempuyang gajah, jahe merah, daun kapulaga, daun lengkuas, jeruk purut, jeruk susu, jeruk nipis jeruk sunde, jeruk kelele, jeruk pagar, jeruk puraga, dan rempah ratus.

\section{Sembur}

Sembur dalam bahasa Karo dikenal juga dengan istilah belo penurungi yang berarti obat Sembur. Obat sembur digunakan untuk mengobati mata yang kabur dan penat di kepala. Penggunaan pengetahuan lokal ini dilakukan dengan cara membalurkan ramuan yang telah dikunyah oleh penyembuh pada bagian kening seseorang yang sedang sakit. selain itu, sembur juga dapat digunakan kepada bayi yang rewel. Adapun tumbuhan yang digunakan untuk menyembur biasanya dengan menggunakan sirih, gambir, pinang, kapur sirih, yang dikunyah oleh penyembuh kemudian dibalur pada sekujur tubuh bayi. Di samping itu juga, ada juga istilah sembur beltek berkhasiat untuk mengobati penyakit di sekitar perut, seperti diare, sakit perut, tidak nafsu makan, asam lambung, dan masuk angin. Rempahnya terdiri atas buah labu, daun jambu yang digiling, temulawak, beras, daun-daunan hutan, jahe, kunyit, lada, dan bawang merah. Semua tanaman herba tersebut digongseng kemudian ditumbuk. Cara penggunaannya selain dapat langsung dikunyah hingga halus kemudian disemburkan, tetapi juga dapat dikonsumsi secara langsung. Pemasaran sembur umumnya di pasar-pasar seperti Pasar Kabanjahe, Pancurbatu, Delitua, dan Tigabinanga.

\section{Erpangir Ku Lau}

Erpangir ku lau merupakan salah satu ritual mandi dengan rempah - rempah yang telah didoakan yang dipandu oleh seorang Guru Sibaso (dukun) atau penyembuh dengan tujuan untuk menyembuhkan penyakit, baik penyakit medis maupun penyakit supranatural. Selain itu, kegiatan ini juga bertujuan sebagai wujud syukur kepada Tuhan. Akan tetapi, untuk alasan ini sebagian besar Etnis Karo sudah meninggalkannya karena tidak sesuai dengan ajaran agama. Tujuan paling umum seseorang melaksanakan tradisi ini adalah untuk menyembuhkan diri dari suatu penyakit. Penyakit yang dimaksud umumnya yang berasal dari penyakit gaib seperti terkena guna-guna, diganggu hantu, dan lain sebagainya. Kegiatan ini umumnya menggunakan perasan air jeruk dan berbagai bunga-bunga, serta sesajian.

\section{SIMPULAN}

Pada akhirnya, hubungan manusia, lingkungan, dan kebudayaannya adalah tiga hal yang saling memengaruhi dan tak dapat terpisahkan. Proses adaptasi manusia pada lingkungannya, membuat manusia menciptakan berbagai perilaku untuk mendukung kehidupannya. Sebagaimana diketahui pada Etnis Karo yang sampai hari ini meski mengalami pengaruh perubahan zaman, tetapi masih tetap melestarikan berbagai pengetahuan lokal yang dimilikinya. Kearifan lokal ini ternyata didukung dengan kepedulian masyarakat dalam membudidayakan berbagai tanaman lokal dan mencari berbagai tumbuhan lokal untuk diketahui khasiatnya. Apabila para generasi mudanya tidak meninggalkan berbagai pengetahuan lokal Etnis Karo, maka akan menjadi sebuah kekayaan budaya tersendiri bagi generasi Karo karena telah mampu mempertahankan dan mengembangkan kebudayaannya. Selain itu diperlukan kajian lebih lanjut khususnya pada dunia medis terkait khasiat berbagai tumbuhan lokal dan publikasinya sehingga beberapa bentuk kearifan lokal yang keliru penggunaannya, seperti kegiatan menyuntil, dapat diketahui khalayak Karo.

\section{DAFTAR PUSTAKA}

Anonim. (2016). Karo dalam Angka 2016 (Karo in Figures 2016). Karo: Badan Pusat Statistik Kabupaten Karo Arkanudin. (2007). Sistem Perladangan dan Kearifan Tradisional Orang Dayak dalam Mengelola Sumber Daya Hutan, dalam http://www.kaltimpos.co.id diakses pada 02/06/2017.

Bathlimus, dkk. (2007). Kearifan Lokal dalam Pengelolaan Sumber Kelautan di Kabupaten Aceh Besar. Banda Aceh: Suwa-BPSNT. 
Sihar Pandapotan, Khairat \& Syahril. Inventarisasi Kearifan Lokal Etnis Karo dalam Pemanfaatan Etnobotani di Kabupaten Karo.

Fien J, H. (1997). Indigenous Knowledge and Environmental. Ferreira A editor Learning for a Sstainable Environment. UNESCO Asia-Pacipic Centre of Educational Innovation for Development and Griffith University Centre.

Gobyah, I.K. (2003). Berpijak pada Kearifan Lokal, dalam http://www.balipos. co.id. diakses pada 17 Juni 2017.

Gough, S. (1997). Kekalahan Manusia Petani. Dimensi Manusia Dalam Pembangunan Pertanian. Yogyakarta: Kanisius. Iskandar. (2009). Metodologi Penelitian Kualitatif. Jakarta: Gaung Persada.

Munawaroh, E. Inggit, P.A. (2000). Peranan Etnobotani Dalam Menunjang Konservasi Ex-situ Kebun Raya. (Seminar Nasional Fakultas Biologi UKSW). Universitas Kristen Satya Wacana. Salatiga.

Ridwan, N.A. (2007). Landasan Keilmuan Kearifan Lokal, Ibda', Vol.5, No.1. Purwokerto: P3M STAIN - Purwokerto.

Suryadarma, I.G.P. 2008. Diktat Etnobotani. Jurusan Pendidikan Biologi FMIPA UNY. Diunduh pada laman http://staffnew.uny.ac.id/upload/130530813/pendidikan/DIKTAT+ETNOBOTANI.pdf Diakses pada 17 Juni 2017. 